ISSN1331 - 677X (UDK 338)

May $30^{\text {th }}-$ June $1^{\text {st }} 2013$

\title{
LONG-TERM OPTIMISATION FUNDAMENTS OF PENSION SYSTEM IN CROATIA
}

\section{Goran Luburića, Neven Šipićb}

${ }^{a}$ Assistant, Zagreb School of Business, Department of Marketing, Ulica grada Vukovara 68, Zagreb, Croatia, goran.luburic@vpsz.hr.

b Assistant, Zagreb School of Business, Department of Marketing, Ulica grada Vukovara 68, Zagreb, Croatia, neven.sipic@ vpsz.hr.

\section{ARTICLE INFO}

Keywords:

- Croatia

- pension system

- pension insurance

- reforms of pension system

- demographic changes

\section{ABSTRACT}

This article examines and presents thoughts on previous and recent analyses of pension system in Croatia, after which authors identify main conclusions and present strongholds towards future optimization of pension system in Croatia. Main points considering optimization come from analyzed and projected effects of different case scenarios, in particular changes and/or reforms in Croatian pension system. All the significant intellectual contributions on pension system are analyzed from the period of pension reforms in Croatia from 2002 until 2011, along with some recent but significant analyses. This study also identifies fundamental problems in Croatian pension system and presents a new perspective considering the direction of potential future changes with having the increase in level of sustainability and monetary pension levels as primary goals.

Reference to this paper should be made as follows: Luburić G, Šipić N. 2013. Long-term optimisation fundaments of pension system in Croatia, Ekonomska istraživanja - Economic Research Special Issue 2013 


\section{INTRODUCTION}

Croatia, as well as other developed countries, awaits unfavorable demographics movements. It is hard to be optimistic in view of future parameters in pension system, other social-functioning systems, economic growth and prosperity. Goals of social politics, in relation to pension system, should be a crucial factor in maintaining social stability, based on long-term sustainability, not short-term solutions such as current plenteous pension payments and use of state budget funds in lack of better measures. Considering demographic changes and changes in macroeconomic variables such as structured unemployment due to uncoordinated labour market supply and demand, that is, shut-down of old and expansion of new business markets, still questionable economic development strategy of Croatia, cyclical changes of economic recession and recovery, pension system, as one of the pillars of social stability, is at a disadvantegous position irrespective of pension reforms that occured ten years ago. The above-mentioned is enough to research the future characteristics of Croatia's pension system in 21st century, especially the issue of sustainability (optimal point) in the next few decades.

Consequently, authors are considering issues related to one of the pillars of social wellbeing: Croatia's pension insurance system. Criticism of pension system's sustainability is emerging after pension reforms of 1999. and 2002. and in the last ten years.

Authors are planning to research possible effects of restructuring the existing pension pilars (I. i Il. pension pillar). However, few complex qualitative questions arise from getting into settings of mentioned pension pillars: should the pension system strive to achieve greater individualisation as a new paradigm in planning financial security at old age or should it primarily stay in state's domain, for it is the creator of social stability? Should the pension system be optimized as a burden for other systems in the sphere of public finances (mainly thinking abouot tax and non-tax income deductions)?

\section{WHAT CAN WE EXPECT FROM CROATIA'S PENSION SYSTEM IN FUTURE?}

Very likely structural changes. However, to explain the base for changes in pension system, one needs to analyse the issue. Thereat the authors emphasize former contributions (until this paper was written) in analysing the state of pension system mainly relying on the results of „Analysis of pension system“ project (Institute for public finances and Bank magazine), „Challenges and possabilites for achieving proper age pensions in Criatia (a study by the Economy institute), and also individual contributions of certain authors.

\section{Sustainability of pension system}

Many factors affect movement in pension system's parameters that mainly belong in demographic and economic factor groups, from the fertility rate and expected life expectancy, movement of young work-active population and older population up in to the employment level, PAYG pensions' level of budget payments, all under one indicator in pension system: proportion of active insured people and retirees (i.e. rate or coefficient of dependence). 
TABLE 1 - NUMBER OF INSURED PEOPLE AND PENSION USERS FROM 1980 TO 2011.

\begin{tabular}{|c|c|c|c|}
\hline Year & $\begin{array}{l}\text { Policyholder } \\
\text { (in thousands) }\end{array}$ & $\begin{array}{c}\text { Retirees } \\
\text { (in thousands) }\end{array}$ & $\begin{array}{l}\text { Relation (rate fo de- } \\
\text { pendence) }\end{array}$ \\
\hline 1980. & 1816 & 449 & 4,04 \\
\hline 1985. & 1931 & 524 & 3,68 \\
\hline 1990. & 1968 & 656 & 3,00 \\
\hline 1995. & 1568 & 865 & 1,81 \\
\hline 2000. & 1381 & 1019 & 1,36 \\
\hline 2004. & 1460 & 1066 & 1,37 \\
\hline 2005. & 1507 & 1078 & 1,40 \\
\hline 2006. & 1538 & 1100 & 1,40 \\
\hline 2007. & 1579 & 1121 & 1,41 \\
\hline 2008. & 1605 & 1148 & 1,40 \\
\hline 2009. & 1530 & 1174 & 1,31 \\
\hline 2010. & 1512 & 1211 & 1,25 \\
\hline 2011. & 1485 & 1212 & 1,23 \\
\hline 2012. & 1433 & 1217 & 1,18 \\
\hline
\end{tabular}

Source: combined statistical data from HZMO (available at www.mirovinsko.hr)

As seen in table 1, it can be intuitively concluded that financial sustainability of PAYG system is esentially unsustainable for more than a decade, if direct payments from state's budget are excluded. In 2011 they amounted for about $85 \%$ of total collected pension contributions (2011. yearly HZMO financial report, available at www.mirovinsko.hr). Plainly speaking, for every 100 kunas of collected contributions from active insurees (those that work), $85 \mathrm{kn}$ is extracted to cover current expenditures for pensions. Additional reason for worrying lies in a fact that this financial situation, in a pension system, occurs even after conducted pension reforms of 1999 and 2002 (accepting the time cost of the reform - implicit debt). It should be noted that authors in this research do not emphasize the analysis of conducted pension refors so far, but synthesize potential paths in restructuring Croatia's pension system based on existing analyses of other authors linked with current (almost a decade after conducted reforms) and future projected states of pension system in the next few decades. 


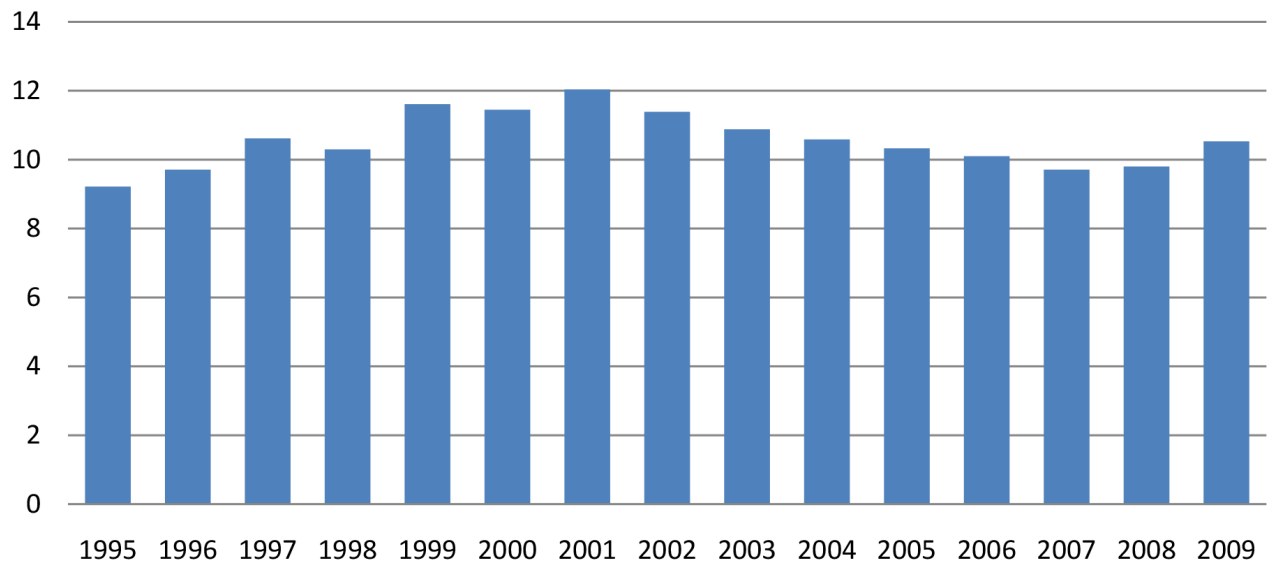

FIGURE 1 - PROPORTION OF CROATIAN PENSION EXPENDITURES IN CROATIAN GDP (IN \%) Source: combined statistical data from HZMO (available at www.mirovinsko.hr)

The question about pension system's sustainability, at least so far, did not come into consideration. To be more accurate, no matter of the financial image of pension system (mainly PAYG system, under HZMO), budget funds are those that were „putting out fires“ every time. Summa summarum, the existance of pensions and socially aware country, in this context, is to protect the egistential level of people of old age. Having that in mind, one should not forget that the main function of pension system is to serve individuals and their families as a mechanism that will enable the allocation of expenditures throughout their lives, especially after a period of employment, in case of disability or loss of breadwinner, that is, when insurees are not able to earn for their living (Puljiz, 2007). It can be concluded that for society as a whole, and especially for the state, social peace in society is equally as important as pension system.

Authors emphasize the term pension system sustainability as well as optimisation (or level of optimisation) of Croatia's pension system. How is optimisation of pension system monitored? What parameters are used? Authors are considering the optimisation of pension system by observing two perspectives: financial sustainability of pension system and its product- pensions, that is, the level of pensions.

How to observe financial viability of pension system? It is already known that pension system is financially not viable for a long period of time. However, Croatia is not an exception. Many european countries have been reforming their pension systems in the last two decades, with different outcome. "Forces of resistance and inertion acted against the reforms, which caused late reaction on observed issues, as opposed to objective circumstances that determined necessary adjustments. Therefore short-term reforms were usually chosen. They mantain basic structure, and gradually change certain elements of pension system with so-called parametrical reforms" (Nestić et al., 2011::10). State intervention in terms of budgetary payments for pensions, aside from collected contributions, is a common occurence in countries with adverse demographic structure. Moreover, Croatia is no exception when it comes to this. High portion of expenditures for PAYG pensions in Croatia's GDP is not a problem, but a consequence. Also, individual capitalized retirenment accounts (II. pillar + III. pillar) are not the only fundamental solution, which will be presented later in this paper.

The problem, besides unfavorable demographic parameters and relatively high unemploy- 
ment (poor ratio between insurees and retirees) lies in structural imbalance of public (PAYG) pension system. Structural problems include unfavorable structure of pension users in relation to their age, years of service and type of pension they receive.

Authors list some of the conclusions (Bađun, 2011.):

- Croatia's retirement system warped with numerous special regulations

- The result of it is additional weakening of the relationship between paid contributions and pensions

- Large number of retirees is somewhat privileged when observing deposited payments, considering how long they receive pensions while having insufficient years of service

- Intergenerational solidarity connotes reciprocity; when speaking about retirees and their rights, it should not be forgotten that young people are future retirees

It should be noted that the average pension time of age pension user in 2010 was 32 years, while average pension time for all users was 29 . Average pension time slightly increased in the last decade, for about a year. There was only 11,7 percent of retirees with pension time of 40 and more years in 2010. Both indicators do not encompass Croatian military pension users, Croatian war defenders and Croatian Defense Council, meaning the average time that would include all retirees is surely lower (Nestić et al., 2011::20).

Authors emphasize the issue of premature retirement. One third of all new retirees in 2010 were premature retirees (Rismondo, 2011). Most often, the cause of retirement was „out of necessity" for those who had that option, mainly encouraged by unfavorable economic conditions in Croatia since 2008. Insurees in individual professions (craftsmen, farmers, etc.) - who paid retirement contributions for themselves, pay only one third of required contribution payments, since their base (65\% of average wage from January-August of the previous year) from which they pay contributions is not related with their wages (Zuber, 2011,274). Zuber notes the reasons are very unclear and are probably not only economic, but also indicate a disbelief in the state system and are trying to avoid paying all public contributions. Moreover, craftsmen obtain a right to retirement after being insured for 15 years which makes it possible, for example, to own a business for 35 years, and not pay contributions for 20 years and still get a right to a pension (and are also protected by the lowest retirement policy).

Total loss in contributions from PAYG retirement insurance, as Zuber estimates, is 2 billion kunas a year (as is indicated in the following graph), due to unpaid retirement contributions from generational solidarity calculated based on average wage salary: 


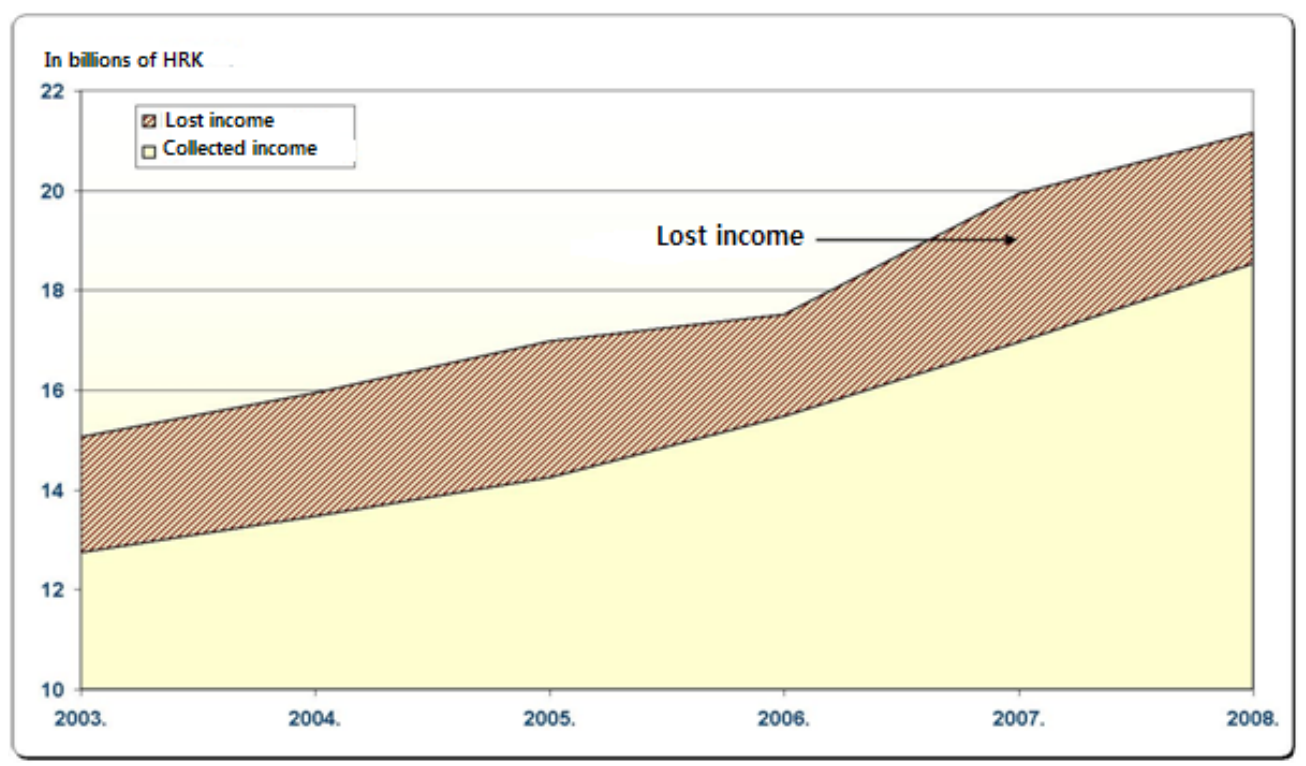

FIGURE 2 - LOSS INCOME FROM RETIREMENT INSURANCE CONTRIBUTIONS OF GENERATIONAL SOLIDARITY FROM 2003. DO 2008.

Source: Zuber, Marija, "Possibilities for advancing socioeconomic and fiscal effects of mandatory retirement insurance system in Croatia", doctoral dissertation, University of Rijeka, College of Economics, 2011.

This renting mentality is an expectation that someone else will take care for the individual (state?). More precisely, almost one third of retirees get their retirement set without acknowledging the principle of reciprocity between paid contributions and the level of retirement rights (Zuber, 2011::243).

To visually percieve the relative optimisation of pension system's parameters, financial parameters of PAYG pension insurance system and healthcare system of Croatia in 2010. will be compared. Although systems have different purposes, they are conceptually similar: both take a portion of individual's salary that is later used by HZMO and HZZO.

TABLE 2 - PAYG RETIREMENT SYSTEM (1ST PILLAR) AND PUBLIC HEALTHCARE SYSTEM (IN 2010.) COMPARISON

\begin{tabular}{|c|c|c|c|c|c|}
\hline $\begin{array}{c}\text { Contributions from } \\
\text { wages (income) }\end{array}$ & $\begin{array}{l}\text { Nominal in- } \\
\text { come from } \\
\text { gross salaries }\end{array}$ & $\begin{array}{l}\text { Collected con- } \\
\text { tributions in } \\
\text { thou. of kunas }\end{array}$ & $\begin{array}{l}\text { Additional pro- } \\
\text { ceeds from in } \\
\text { thou. of kunas }\end{array}$ & $\begin{array}{c}\text { Percentage } \\
\text { of proceeds } \\
\text { from budget } \\
\text { for mentioned } \\
\text { systems }\end{array}$ & Ratio \\
\hline $\begin{array}{l}\text { Contribution for re- } \\
\text { tirement insurance }-1 \text {. } \\
\text { tier }(\mathrm{HZMO})\end{array}$ & $15,0 \%$ & 19153377 & 16259950 & $85,81 \%$ & $6 x$ \\
\hline $\begin{array}{l}\text { Contribution for man- } \\
\text { datory health insur- } \\
\text { ance }(\mathrm{HZZO})\end{array}$ & $15,0 \%$ & 17185633 & 2689056 & $14,19 \%$ & $1 x$ \\
\hline
\end{tabular}

Source: combined data from HZMO, HZZO and country's budget for 2010 - financial report 
Table 2 clearly shows the extent of potential synthetic level of retirement and healthcare system optimisation in Croatia. While nominally identical amounts from wages are outshined for pension and healthcare insurance (which is questionable by itself, considering the demografic movements, this level of proceeds for retirement contributions cannot meet the payout of current pensions- pension are needed by retirees every month, on the other hand, healthcare services are not needed from every citizen every month in a year, based on the law of big numbers), PAYG retirement budget has funds six times larger than for the needs of healthcare system. The question here is whether funds six times larger for PAYG in relation to budgetary expenditures for public healthcare system is a real level of optimized pension system, or is there space for optimisation?

When hypothetically simplifying a mathematical calculation of costs for pension expenditures, for example, ratio between insurees and retirees $=1,23: 1$, contribution charge from salary $=100 \%$ (really under $90 \%$ ), contribution from brutto salary for 1 st pension pillar of $15 \%$ results in aproximately $20 \%$ amount of net pension (authors' own calculations based on pondered average of income groups in Croatia, according to National agency for statistics - „Employment and wages in 2010"), payment of pensions only from PAYG system (1st pillar), we would get the following rough financial indicators that need budgetary intervention in the pension system: the amounts of collected contributions would cover $24,6 \%$ of net pensions amount in relation to net salaries, on which we would have to add additional $15,4 \%$ (or $62,6 \%$ of total collected contribution amount) from budgetary transfers to get a portion of net pension in net salary of about $40 \%$, which is average rate of exchange for the past few years. However, state adds $20,1 \%$ (or $85 \%$ of amount from total contributions) to achieve identical rate of exchange, which is $30,51 \%$ more. From that $30,51 \%$ of transfers from the budget, the state finances the difference for disability, defense, family, and privileged pensions, the deficit from paid contributions, pension growth rate, transitional expense of pension reform and HZMO expenses (HZMO covers its expenditures with paid contributions, however, it is still not a key factor and is insufficient for total budgetary billing results for pension system). The $30 \%$ increase for 2010 translates to 5 billion kunas a year, which is the amount around which can be manevred to optimise Croatia's pension system.

Furthermore, how do finances look for PAYG pension insurance system in the future? To get the idea of projected future movements in relation to financial sustainability of pension system, authors emphasize results of a study from Institute for economics (Nestić et al., 2011.), shown on the following graphs: 


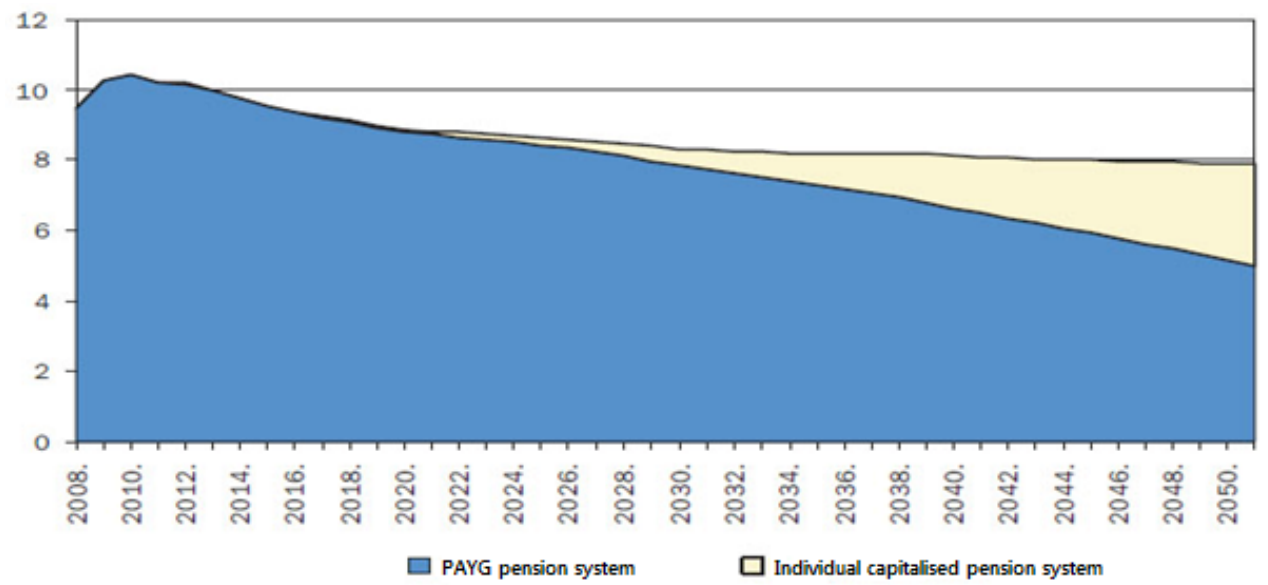

FIGURE 3 - PROJECTED EXPENDITURES FOR PENSIONS IN CROATIA, IN \% OF GDP

Source: Challenges and possibilities for achieving proper age pensions in Croatia - a project study - Institute for economics, Zagreb, September 2011.

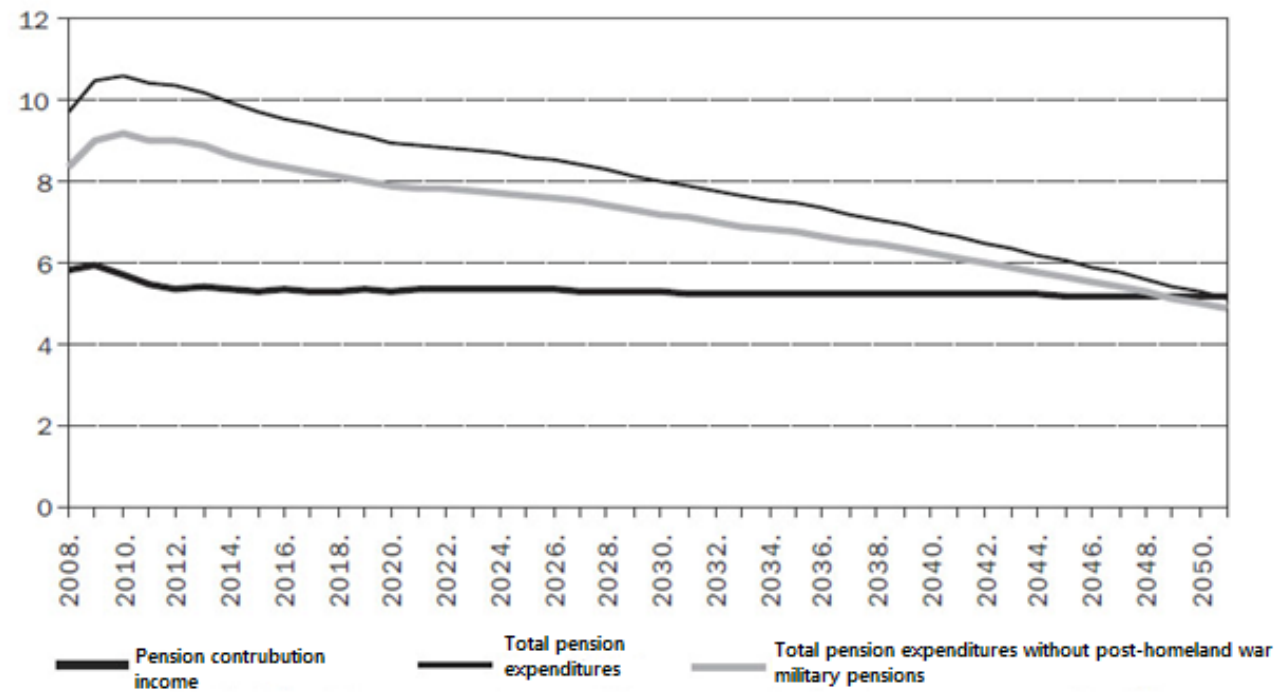

\section{FIGURE 4 - PROJECTED CONTRIBUTIONS AND TOTAL EXPENDITURES FOR PAYG PART OF THE PENSION SYSTEM IN CROATIA}

Source: Challenges and possibilities for achieving proper age pensions in Croatia - a project study - Institute for economics, Zagreb, September 2011.

Methodology of calculating projected fiscal effects of demographical changes is based on long-term projections of population movements and set of economical assumptions of future movements. According to the projected employment, a gradual increasing rate of activity occurs because of three reasons: 1) economic crisis recovery, 2) female average increase in age limit for pensions and 3) convergence of activity rates towards rates expected for the new EU member countries. Average projected rate of GDP increase from 2010.-2050. is 2,2\% per year, while the rate of productivity is projected to be $2,5 \%$ per year. Having that in mind, the relation between insurees 
and retirees could increase approximately 1,3:1 untill 2010, as projected. After that it would gradually decrease to approximately 1,05:1 around year 2050.

The before-mentioned study assumes that if current policies are valid for the whole period of indicator's fiscal sustainability of pension system's projection, that projected decrease in expenses leads to gradual decrease in public pension system's deficit, which should dissapear by 2050, that is, all retirement payments from PAYG system would be covered with earnings from contributions. This is not a usual trend in the EU, where an increase in expenditures is expected.

In explaining the effect of decreasing pension expenditures, authors note the aging population that will push pension expenditures of PAYG system upward. However, effects of other factors (relative pension level, retirement ratio, dependency ratio, employment effect) will act in opposite direction, mainly decreasing pensions, which will ultimately cause a decrease in portion of pension expenditures in GDP (up to 50\%). The decrease in public expenditures for pensions shoud be slightly stronger in 2030-2050 period (parameters for this period are harder to predict) then in 2010-2030 period. It is interesting how the turning point in expenditures growth (according to graph 4.) is actually year 2010.

In comparison, results from World bank study (Croatia: Policy Options for Further Pension System Reform, 2011.) indicate that PAYG pension insurance system will need few years less for the same effect of balance in public pension system. However, since the different calculating methodologies, results from both studies should be taken with reserve. It is a long period of preasure on public finances in context of budget deficit and secondary pressure on public debt. Authors believe the above mentioned is enough to continue restructuration, reforms and general Croatia's pension system optimisation.

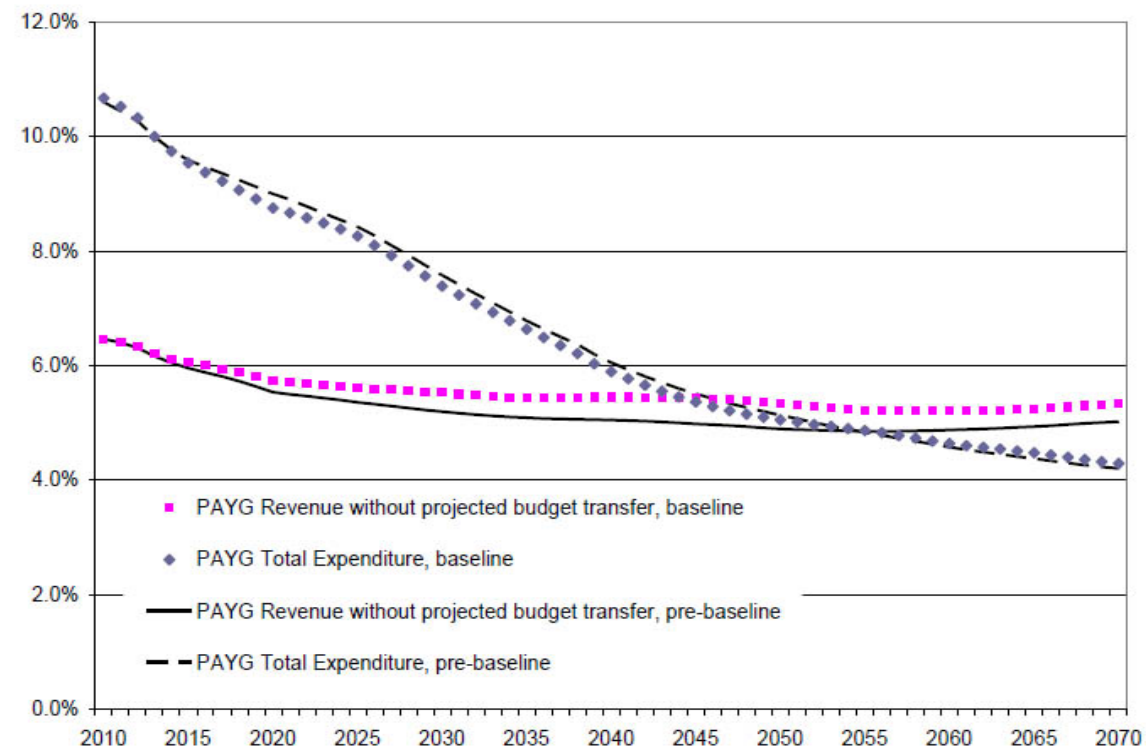

FIGURE 5 - PROJECTED CONTRIBUTIONS AND EXPENDITURES FOR PAYG PENSION INSURANCE SYSTEM IN CROATIA, IN \% OF GDP

Source: "Croatia: Policy Options for Further Pension System Reform", World bank, 2011.

Mentioned projected balance is achieved through replacement rate, that is, with the decrease 
in part of average net pension in average net salary on levels below 30\% (which is currently the border level for retiree poverty) which brings a question: Is that a goal for sustainable level of pensions? We could assume that budgetary transfers for current pensions will hardly dissapear (so that goals of social politics would not diminish in significance - one of which could be keepeing adequate levels of replacement ratio), but relative portion of those transfers in overall expenditures for pension system should decrease over time. To what level? It depends on demographic factors, state of economy- already assumed, and future level of pension system's optimisation.

\section{Future retirement levels}

When this research was written, the average pension was around $40 \%$ of average net salary in Croatia (replacement rate). Later in the text, this indicator will be used in projections for future pension levels. We can hardly find out retirees' real income from the replacement rate. How much does the average replacement rate of $40 \%$ really reflect on retirees' real income in period of ten years after conducting the last retirement reform in Croatia?

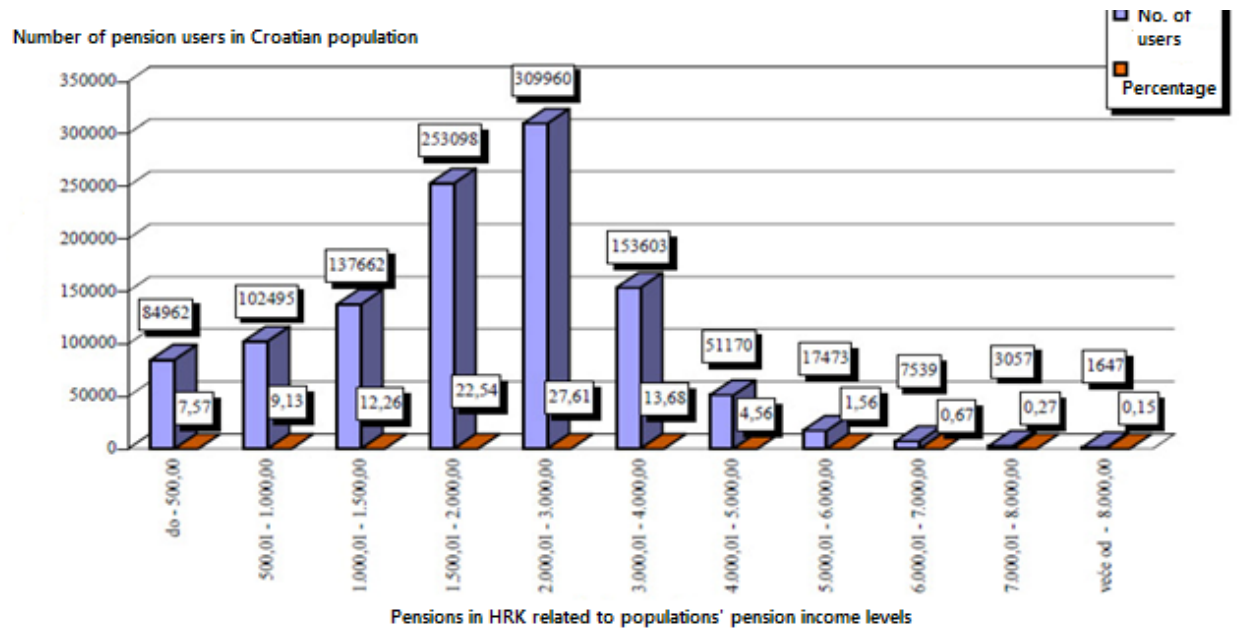

\section{FIGURE 6 - STRUCTURE OF PENSION USERS ACCORDING TO PENSION AMOUNTS FOR SEPTEMBER OF 2011.}

\section{Source: Statistical information from HZMO, no. 3/2011.}

In his analysis, Ivica Urban (Urban, 2011) compared retirees' consumer basket with their income and stated that for $28 \%$ of retirees, the coverage of consumer basket is under $100 \%$ level, while for $6 \%$ of them, it is below $60 \%$ level. Urban (2011) also indicates the poverty rate of retirees in Croatia (including income in nature) is $27,9 \%$, according to his analysis. According to National agency for statistics, it is $23,7 \%$ for the same observed period. From the before-mentioned, we can assume the retiree poverty rate is between $25 \%$ and $30 \%$, being on $40 \%$ of average replacement rate. The data were current at the time this paper was written. At the same time, the state sets 85 kunas aside from the budget for every 100 kunas of collected pension contributions. Do we have enough excuses to criticize the existing pension system? Could these parameters look better if the replacement rate was lower? Projections on sustainability of pension system mentioned earlier in text actually predicts it, including pensions from second pension tier (individualized capitalised accounts). Nevertheless, replacement rate should be viewed conditionally, since future retiree's real income depends mainly on future retiree's real buying power. 
According to World bank study results (Croatia: Policy Options for Further Pension System Reform, 2011.), the average gross replacement rate (the average rate of gross pension in gross salary) could lower by $10 \%$ by 2050 for so-called old retirees (only 1 st tier), in relation to current state, which is from $38 \%$ to $27 \%$ for men, and from $32 \%$ to $21 \%$ for women. It is of similar movement for so-called old retirees, but on average $5 \%$ lower during period of observation.
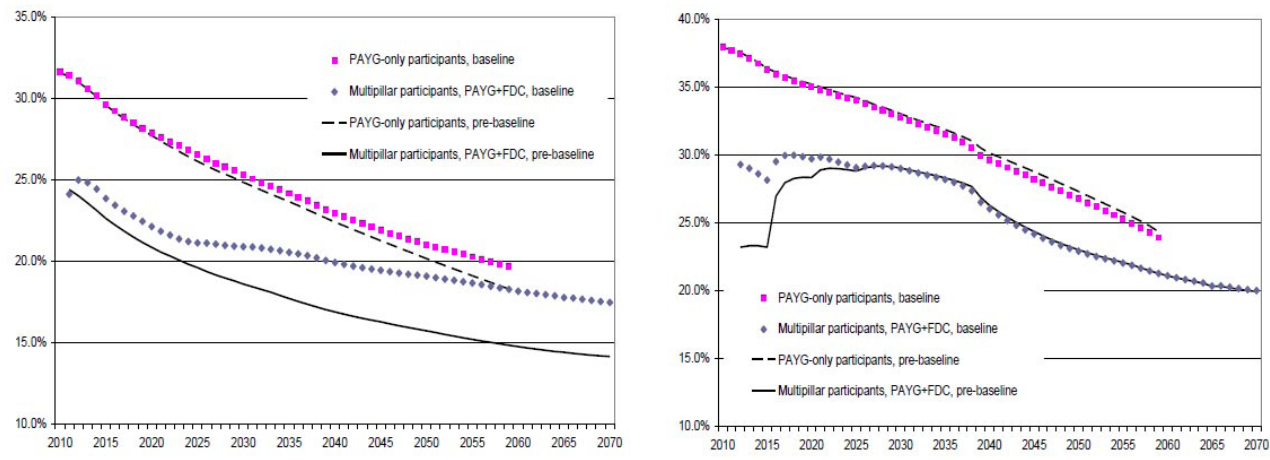

\section{FIGURE 7 - AVERAGE RATE OF GROSS REPLACEMENT FOR WOMEN (LEFT GRAPH) AND MEN (RIGHT GRAPH)}

Source: "Croatia: Policy Options for Further Pension System Reform", World bank, 2011.

It is important to mention that previous graph shows gross replacement rate, not net replacement rate. Although net replacement rate would probably reach 10 more percentage points, it would not, even in best case scenario, reach nowdays net replacement rate of around $40 \%$. When estimating starting gross replacement rate (first pension after last salary), the projection is somewhat more favourable then average gross replacement rate viewed in percentage difference between so-called old and new retirees. However, the decreasing trend during the observation period is also present, as the next graph shows.
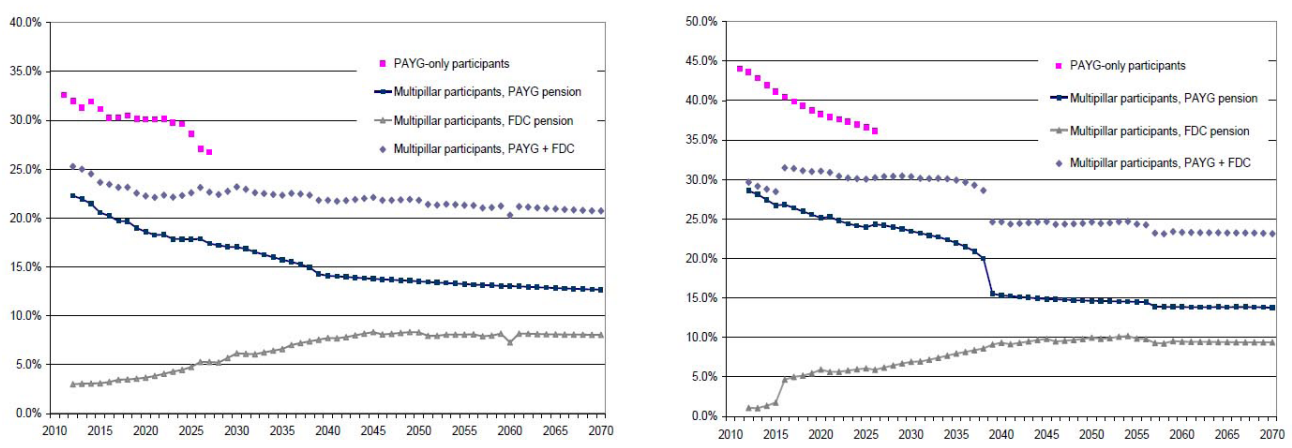

\section{FIGURE 8 - BEGINNING GROSS REPLACEMENT RATE FOR WOMEN (LEFT GRAPH) AND MEN (RIGHT GRAPH)}

Source: "Croatia: Policy Options for Further Pension System Reform", World bank, 2011.

Projected trend of replacement rate decrease during observed period is also effect of so-called Swiss pension calculation (audit) formula (based on ratio of $50 \%$ salary growth valorisation and $50 \%$ indexation towards price level movements. A model used in projection production is so- 
called PROST model (standard World Bank model used in pension system parameter analysis in more than 90 countries in the world). Macroeconomic indicators used in previous projections are as follows:

TABLE 3 - MACROECONOMIC ASSUMPTIONS IN WORLD BANK'S STUDY OF PENSION PROJECTIONS (AVERAGE ACCORDING TO PERIOD)

\begin{tabular}{lcccc}
\hline \hline & 2011.-2012. & 2013.-2020. & 2021.-2035. & 2036.-2070. \\
\hline \hline $\begin{array}{l}\text { Average employment growth } \\
\text { (year per year) }\end{array}$ & 1,1 & 1,5 & $-0,2$ & $-0,7$ \\
Real salary growth rate & 1,1 & 2,7 & 2,2 & 2,2 \\
Inflation rate & 2,8 & 3,0 & 2,9 & 2,5 \\
Real GDP growth & 2,3 & 3,9 & 2,1 & 1,5 \\
\hline \hline
\end{tabular}

Source: "Croatia: Policy Options for Further Pension System Reform", World bank, 2011., pg. 19

Relatively similar pension system movements projections were found in before-mentioned study by the Institute for economics, which used the following assumptions (Nestić et al., 2011.):

- Laws did not change in the projections period

- Average yearly growth of real salaries is $2,6 \%$, the same as yearly growth rate of real salaries for EU-12 (new EU members)

- Yearly inflation rate is $2 \%$

- Yearly real netto yield from pension funds is $2,5 \%$ (in accumulation phase), and $1,7 \%$ in payment phase (yield decreased for all restitutions)

- Brutto and netto replacement rate is defined as beggining, and not average replacement rate (i.e. as first pension in relation to the last salary)

The study indicates the possibility for Croatia to have the lowest starting replacement rate by 2050 , in relation to current EU member countries, which is roughly $38 \%$ (mix system: $1 .+2$. pillar) as opposed to $55 \%$ (only 1. pillar) in 2010. That would theoretically mean a set-back from 2010, when only Estonia, Romania, and Cyprus had lower replacement rates. Further projection analysis forecasted a decrease in average starting net replacement rates up to $36 \%$ by 2030 . Afterwords, they would stay pretty stable and amount for $36-37 \%$ od net salary, which is explained by reaching the maturity level of individualized capital savings (2nd pillar). However, a slight decrease of replacement rate is projected after 2042, a consequence of "Swiss formula“ effect.

The so-called "Swiss formula" has a negative connotation. In addition, most OECD countries accepted $100 \%$ salary valorisation and $100 \%$ price indexation, in the context of pension funds, for multiple reasons (as is written in before-mentioned study by the World bank): a) such calculation keeps retirees' buying power as time passes, b) brigs fiscal and social benefits in the long-run, c) strenghtens the link between contributions and later benefits from contributions. The qustion is why would the "Swiss formula" stay the the same in the Croatian example? The reason for it may be found in short-term and mid-term increasing pressure on budgetary expenses. 


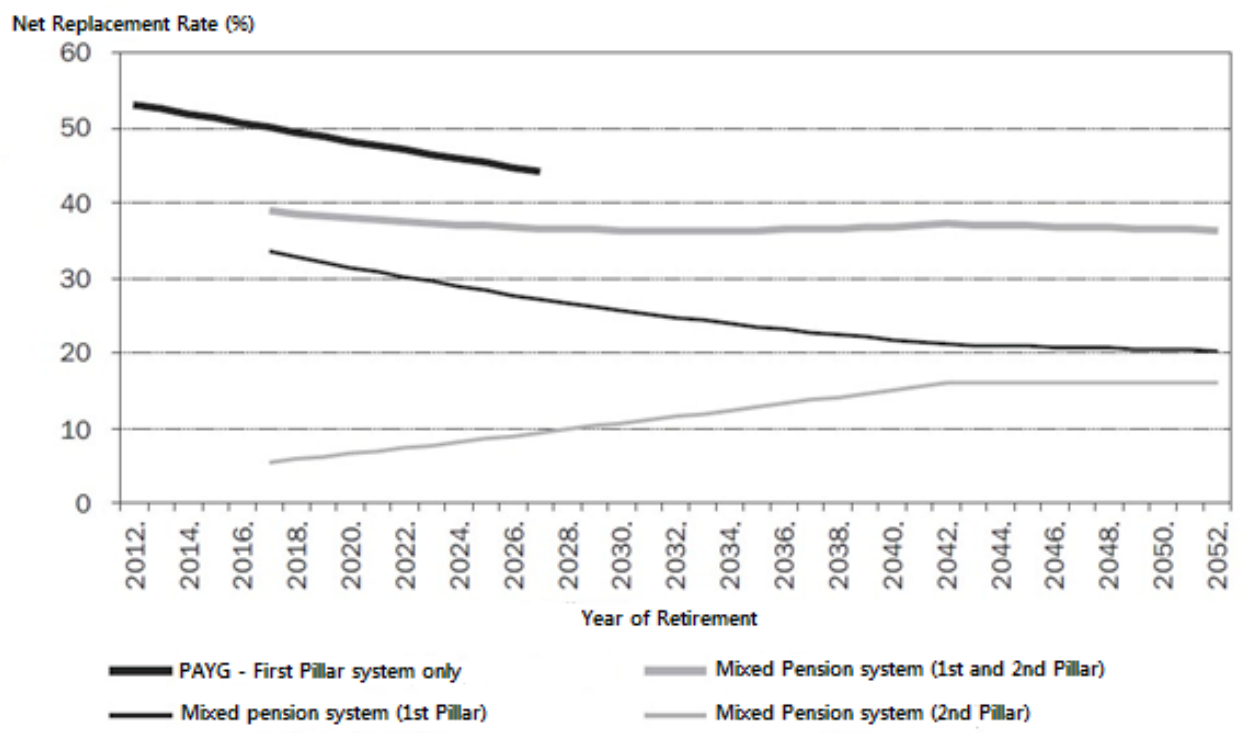

FIGURE 9 - AVERAGE RATE OF NET REPLACEMENT FOR „AVERAGE“ WORKER (2012.-2052.)

Source: Challenges and possibilities for achieving adequate age pensions in Croatia - project study - Institute for economics, Zagreb, September 2011.

N.B.: 'average' worker is defined as a person that goes to age pension after 65 years of age and 40 years of work experience, assuming he/she received average wage for all his/her life.

Unlike World bank's study that indicated average growth rates of real salaries between 2 and 2,5\% without spillover effect on pensions' buying power, a study by Institute for economics quantifies future pensions' buying power, taking the assumption of 2,5\% real salaries growth. Whilst, the study indicates, pensions' buying power could increase $20 \%$ by 2027 , and $50 \%$ by 2050 . These indicators sound optimistic when observing pensions buying power separately. If we discount such optimistic assumptions to current net replacement rates, it would mean an equivalent level higher then $55 \%$ of net replacement rate. However, it is hard to expect similar life circumstances and material trends for such a long projection period. Not to mention, currently the safest assumption is for demografic indicators, in relation between insurees and retirees up to 2050, will not reach the level of two employees on one retiree (Luburić, 2010.:46). Intuitively speaking, very little can be expected from from positive demographic movements. On the other hand, the average worker's material life expenses are increasing. It is possible that level of material survival is easier to reach nowadays. However, if projections were to be right, it would automatically mean that mid-class employees could have higher buying power. Would they fit in today's mid-class? The assumption is that current low, mid, and high income groups will be rated differently in 2050. Therefore, the before-mentioned percentage gap in replacement rate could possibly be negatively related to pension levels.

Morevoer, according to projections by the Institute for economics, a slow decrease is expected (first pension's net replacement rate in relation to salaries and like ten years after the retirement), precisely: 
TABLE 4 - NET REPLACEMENT RATE FOR A TYPICAL WORKER IN RETIREMENT PHASE AND TEN YEARS AFTER THE RETIREMENT

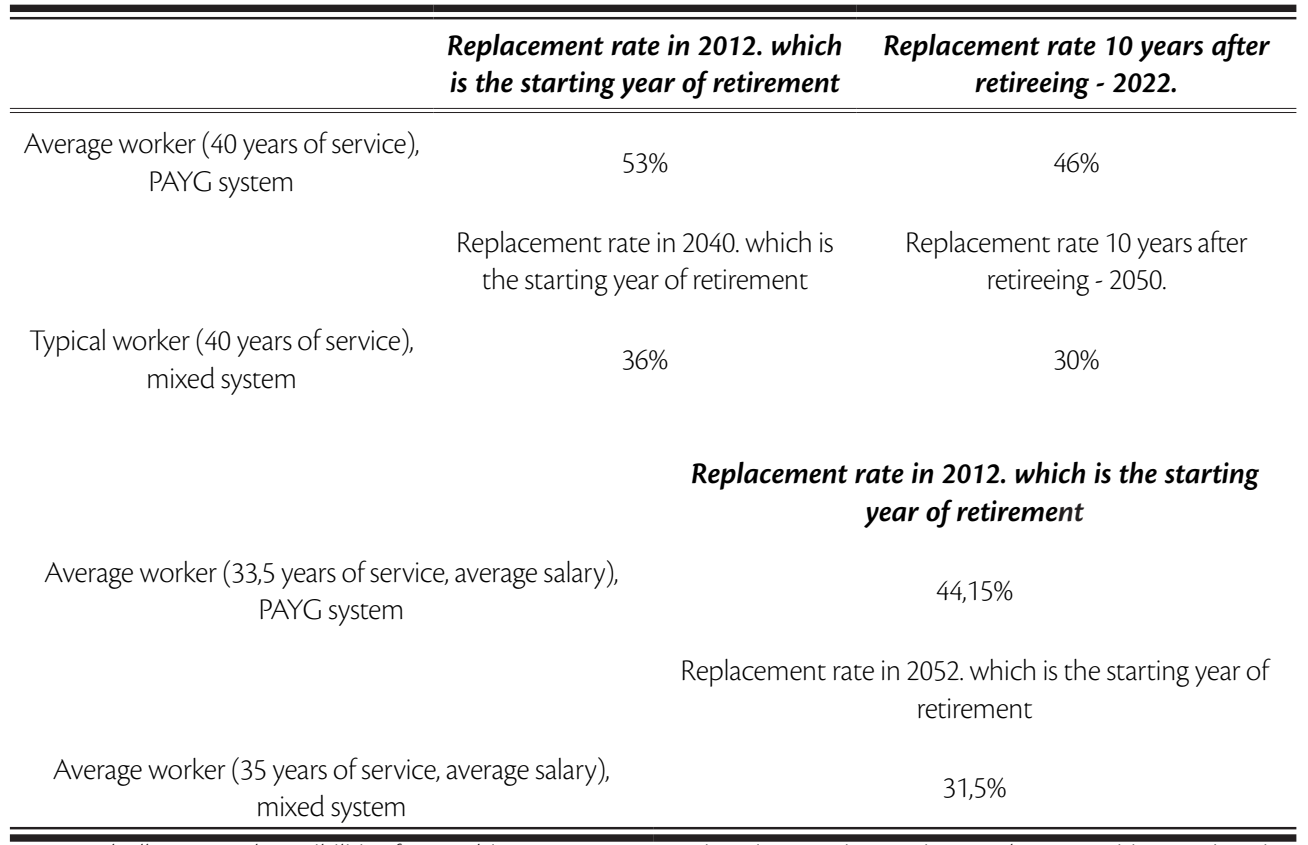

Source: Challenges and possibilities for reaching proper age pensions in Croatia - project study - Izazovi i mogućnosti za ostvarenje primjerenih starosnih mirovina u Hrvatskoj - projektna studija - Insitute for economics, Zagreb, September 2011. N.B.: 'typical' worker is defined as a person that goes to scheduled age retirement ( 65 years of age and 40 years of service), assuming the worker received average salary in the country.

A relative decrease in starting replacement rate and current replacement rate ten years after retirement (for pensions in mixed system in relation to those from current PAYG system) is noted. The reason lies in pensions' growth rate which is more for pensions from PAYG system then in mixed system. Capitalised part of pension system indexes pensions only according to inflation, unlike PAYG pensions which are adjusted 50:50, for wage growth and inflation, respectively.

The border line of poverty will have the main role in correlating adequate pensions, considering the longievity of projections. $35 \%$ of average salary is currently a poverty line. Taking the projections into account, in 2052., one would have to earn approximately $75 \%$ of average wage over 40 years of service in order to keep his/her retirement level above the poverty line (Nestić et al., 2011::47).

PAYG portion of the mixed pension is going to decrease with future retirees, in relation to pensions from 2nd pillar. The assumption is that those insurees who spent their entire work life with dual pension system will realize bacis pension from 1st pillar (Nestić et al.,2006.:54).

In the end, the Association of Pension Funds in Croatia (UMFO, 2011.) believs the pension system to be as sustainable as it was in year 2000, since nor the replacement rate nor budgetary transfers have changed for the better in the past ten years. 


\section{CONCLUSION - BASES FOR RESTRUCTURING AND OPTIMISATION OF EXIST- ING PENSION SYSTEM IN CROATIA}

Review of retirement rights in view of expenditure decrease and juctice increase in pension income redistribution solves one important part of the problem - sustainability of pension system through the prism of public finances. However, the before-mentioned pension system's optimisation means adequate pension levels in the future. And in that context, it will be hard to avoid the question about restructuring pension contributions, but also a broader picture on select from insurees' salaries. The remainder of this paper concentrates on adequately finding solutions that could optimize pension levels for new retirees in the long-run.

The following are suggestions on how to improve the sustainability of pension system, categorized by frequency and importance:

- Measures for a potential increase (or no decrease) in future pension levels - measures that mainly touch on assigning money for 1 st/2nd pension pillar

- Propositions on strenghtening the relation between paind contributions and received pensions (also the institutionalization of so-called zero rate - tax or budgetary pillar)

- Propositions suggesting the increase of balance between solidarity (redistribution) and personal care for retirement savings (a notion of individual responsability for receiving income at old age or encouraging personal savings for old age)

- Questions on socially acceptable and fiscally sustainable system of pension valorisation and indexation (i.e. "the Swiss formula - pros and cons)

- Suggestions indicating reconsidering pension rights and solving injustice in existing pension system

When writting about the fundamental changes in the pension system or its restructuring, then an important factor is longevity, as with simple or complex interest account of simple or some sort of exponential function. Small changes can nowadays have multiplicative positive and negative effect in the future. If the pension system is perceived like this, it is partially undestandable that the sinteticity of future projections (i.e. relative inertion in the context of fundamental changes - for simple reasons - they are intouchable, mostlc conceptual). All of it for long-term factor.

On the other hand, if conceptual changes in pension system are viewed exclusively in the long-run, then two most important agregate indicators surface which are indicators of pension system's level of optimisation: its sustainability and pension level. If nothing changes, sustainability of pension system should better in the long-run, as explained earlier. As this are, it should be on future pension level's burden. Therefore, if pension system's optimisation is the goal, then the main fundamental step towards improving is optimising future pensions that would be fiscaly and socially acceptable. The continuation of pension reform should be beamed towards exactly that goal, acknowledging fiscal sustainability of the whole system, as previously set.

The main instruments for increasing future pension levels, while acknowledging all beforementioned measures, are proceeds for pension contributions (1.+2. pillar). Without the increase in proceeds for pension contributions (thinking mainly on 2nd pillar), it is simple to mathemati-

$2 n d$ pillar pension $=\frac{\text { total accumulated netto amount }(\text { decreased for all provisions after yield })}{\text { estimated life expectany after work life }}$ 
cally prove an inability of future pension levels to increase. The following is a simplified calculation:

If the average age at the time of retirement is statistically estimated fixed number, then the only way the total pension can be higher is to increase accumulated amount of paid contributions for 2nd pillar, except for the following two cases: increase in fiscal expenditures (change in the way pensions are calculated) or long-term increase in number of workers in relation to retirees (again the change in the way pensions are calculated). The first scenario is not the aim of pension reform, and the other case is hypothetical. But what we can calculate is finding the "golden middle" between increasing pension contributions or pressures to decrease net worker salaries or even raising the bar for two (costs) gross salaries.

Based on explanations, the authors suggest their own methodology for defining the model of change in the pension system:

1. An increase in proceeds for pension contributions with a goal to restructure 1st and 2nd pension pillars (one of fundamental changes to expected long-term positive effect on financial stability of pension system).

2. Do not create pressure when increasing gross two (cost of salary).

3. Minimalizing the potential pressure to decrease net salary.

4. Correction of other proceeds from gross salary - to open up a space for restructuring pension pilars.

5. Income taxes reform - to completely neutralize any increase in money mass between net salary and costs (gross two) salaries - yet, such ratio needs to be decreased - why? Work needs to be stimulated, not taxed! In that way, tax evasion would loose its importance in the long run.

6. Parallel increase of 1st and 2nd pillar - so-called sliding stair model of pension system- Why increase of both pillars? Increasing the rate of contributions for 1st pillar, we actually neutralize an increase in 2 nd pillar without the need to increase pension expenditures by the state. That positive effect is tranfused into other public finance system's deficits (other contributions from salaries) - so-called proceeds conversion from gross salary. Also, increasing contribution rate for 1 st pillar buys more space for increasing proceeds, in the long-term, once the PAYG pension expenditures show decreasing tendency. That is, when we gradually start going back to $15 \%$ level of PAYG's proceeds rate, or simply exchange the same percentage with the same percentage of proceeds increase for the 2nd pillar.

7. Gradual conversion of the whole system towards NDC (notion defined contribution) models of pension systems (for example, Sweden)

Implications of set bases in the model come from accounting changes in calculating the salary; therefore, an inductive method is used to translate it to all other systems comprised by the salary calculation. Authors emphasize that any changes in the pension system and salary calculations would be insufficient, that is, if other system changes from public finances area are not included, which would destroy defined bases, and therefore motivational factors for changes. 


\section{REFERENCES}

Bađun, M. (2011), "Zašto Hrvatska ima mnogo korisnika invalidskih mirovina", članak pripremljen za projekt "Analiza mirovinskog sustava" u organizaciji časopisa Banka i Instituta za javne financije.

Bejaković, P. (2011), završne preporuke i komentar projekta "Analiza mirovinskog sustava" u organizaciji časopisa Banka i Instituta za javne financije.

Bronić, M. (2007), "Kako se dijele prihodi od poreza i prireza na dohodak", Newsletter - povremeno glasilo, Institut za javne financije, Zagreb.

Državni zavod za statistiku (2011), Zaposlenost i plaće u 2010. - publikacija Državnog zavoda za statistiku.

Državni zavod za statistiku (2012), Statistički ljetopis za 2011. godinu - publikacija Državnog zavoda za statistiku.

Hrvatski zavod za mirovinsko osiguranje (2010), godišnji financijski izvještaj za 2010. godinu. Zagreb: Hrvatski Zavod za mirovinsko osiguranje.

Hrvatski zavod za mirovinsko osiguranje (2011), "Statističke informacije HZMO-a". Zagreb: publikacija Hrvatskog Zavoda za mirovinsko osiguranje.

Hrvatski zavod za zdravstveno osiguranje (2011), financijsko izvješće za 2010. godinu. Zagreb: Hrvatski zavod za zdravstveno osiguranje.

Luburić, G. (2010), "Pretpostavke održivog mirovinskog sustava Republike Hrvatske u ovisnosti o demografskim kretanjima", diplomski rad, Ekonomski fakultet Sveučilišta u Zagrebu, Zagreb.

Ministarstvo financija Republike Hrvatske (2011), Konsolidirani proračun RH - opća država za 2010. godinu. Zagreb: Ministarstvo financija RH.

Nestić, D. i sur. (2006), "Analiza dugoročnih fiskalnih učinaka demografskih promjena”, projektna studija", Ekonomski institut, Zagreb.

Nestić, D. i sur. (2011), "Izazovi i mogućnosti za ostvarenje primjerenih starosnih mirovina u Hrvatskoj", projektna studija, Ekonomski institut, Zagreb.

Puljiz, V. (2007), "Hrvatski mirovinski sustav: Korijeni, evolucija, perspektive", Revija za socijalnu politiku, 14(2).

Rismondo, M. (2011), “Tko se sve ukrcao u I. stup?”, članak pripremljen za projekt “Analiza mirovinskog sustava” u organizaciji časopisa Banka i Instituta za javne financije.

Svjetska banka (2011), "Croatia: Policy Options for Further Pension System Reform", studija Svjetske banke.

Udruženje društava za upravljanje mirovinskim fondovima i mirovinskih osiguravajućih društava - UMFO, (2011),"Mirovinska reforma u Republici Hrvatskoj: dosadašnji učinci, aktualno stanje i prijedlozi za budućnost". Zagreb: UMFO.

Urban, I. (2011), "Koliki je stvarni dohodak umirovljenika”, članak pripremljen za projekt "Analiza mirovinskog sustava" u organizaciji časopisa Banka i Instituta za javne financije. 
Goran Luburić, Neven Šipić

Zuber, M. (2011), “Kakva je veza između uplaćenog doprinosa i mirovine”, članak pripremljen za projekt "Analiza mirovinskog sustava" u organizaciji časopisa Banka i Instituta za javne financije.

Zuber, M. (2011), “Mogućnosti poboljšanja socioekonomskih i fiskalnih učinaka sustava obveznog mirovinskog osiguranja u Hrvatskoj", doktorska disertacija, Ekonomski fakultet Sveučilišta u Rijeci, Rijeka. 